DOE/MC $--96 / C$ O $5 / 4$

Pilot Scale Experience on IGCC Hot Gas Cleanup

Authors:

Kari Salo

Reza Ghazanfari

Gabor Feher

Jukka Konttinen
Reza Ghazanfari

Arto Lehtovaara

Wahab Mojtahedi

\title{
Contractor:
}

Enviropower, Inc.

P.O. Box 35

33701 Tampere

Finland

$+358-31-2413511$

\section{Contract Number:}

93-016

\section{Conference Title:}

Advanced Coal-Fired Power Systems '95 Review Meeting

\section{Conference Location:}

Morgantown, West Virginia

\section{Conference Dates:}

June 27-29, 1995

\section{Conference Sponsor:}

U.S. Department of Energy, Morgantown Energy Technology Center (METC) 


\section{DISCLAIMER}

This report was prepared as an account of work sponsored by an agency of the United States Government. Neither the United States Government nor any agency thereof, nor any of their employees, makes any warranty, express or implied, or assumes any legal liability or responsibility for the accuracy, completeness, or usefulness of any information, apparatus, product, or process disclosed, or represents that its use would not infringe privately owned rights. Reference herein to any specific commercial product, process, or service by trade name, trademark, manufacturer, or otherwise does not necessarily constitute or imply its endorsement, recommendation, or favoring by the United States Government or any agency thereof. The views and opinions of authors expressed herein do not necessarily state or reflect those of the United States Government or any agency thereof.

This report has been reproduced directly from the best available copy.

Available to DOE and DOE contractors from the Office of Scientific and Technical Information, 175 Oak Ridge Turnpike, Oak Ridge, TN 37831; prices available at (615) 576-8401.

Available to the public from the National Technical Information Service, U.S. Department of Commerce, 5285 Port Royal Road, Springfield, VA 22161; phone orders accepted at (703) 487-4650. 


\section{CONTRACT INFORMATION}

Cooperative Research and

Development Agreement Number:

93-016

Contractor:

Enviropower Inc.

P.O. Box 35

33701 Tampere

Finland

$+358-31-2413511$

Contractor Administrative Contact: Kari Salo

Contractor Technical Contact:

Reza Ghazanfari

Gabor Feher

Principal Investigators:

Jukka Konttinen

Reza Ghazanfari

Arto Lehtovaara

Wahab Mojtahedi

METC Project Manager:

Thomas P. Dorchak

Period of Performance:

September 8, 1993 to December 31, 1995

Scedule and milestones:

1993-1995 Program Scedule

$1993 \quad 1994 \quad \underline{1995}$

CRADA Agreement

Sulfur Removal Pilot Installations

\begin{tabular}{lllllllllllllll}
\hline & $N$ & $J$ & $M$ & $M$ & $J$ & $S$ & $N$ & $J$ & $M$ & $M$ & $J$ & $S$ & $N$ & $D$
\end{tabular}

Sulfur Removal Pilot Commissioning

Sulfur Removal Pilot Tests

DSRP Pilot Design

DSRP Commisioning

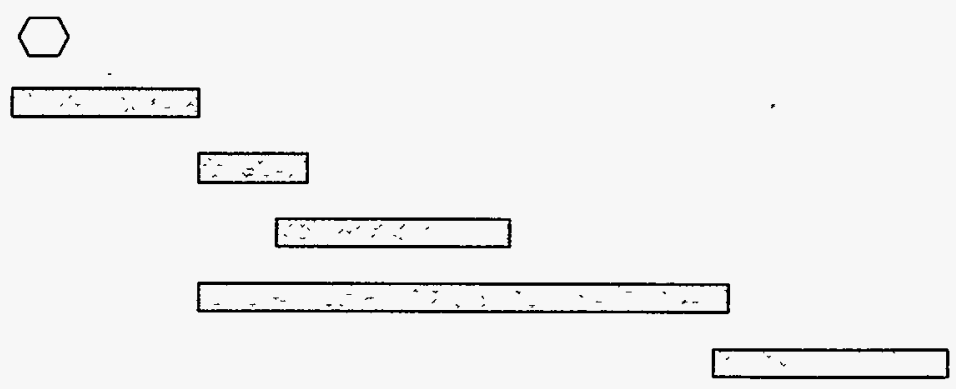




\section{OBJECTIVES}

In September 1993 Enviropower Inc. entered into a Cooperative Research and Development Agreement (CRADA) with the Department of Energy in order to develop and demonstrate the major components of an IGCC process such as hot gas cleanup systems.

The objectives of the project are to develop and demonstrate 1) hydrogen sulfide removal using regenerable metal oxide sorbent in pressurized fluidized bed reactors, 2) recovery of elemental sulfur from the tail-gas of the sorbent regenerator and 3) hot gas particulate removal using ceramic candle filters.

\section{BACKGROUND INFORMATION}

Enviropower Inc. is a subsidiary of Tampella Power Inc. which is the parent company of the Tampella Power Corporation in the U.S.A. Enviropower Inc. is actively involved in the development of the Integrated Gasification Combined Cycle (IGCC) process. Enviropower's IGCC concept incorporates pressurized fluidized bed gasification of different solid fuels, applying air-blown gasification and hot gas clean-up. The IGCC process and the demonstration activities have been described in detail elsewhere $/ 1,2 /$.

Enviropower's pressurized fluidized bed gasification pilot plant has a maximum thermal input of $10 \mathrm{MW}$ (35 mtpd) for coal and $15 \mathrm{MW}$ $(100 \mathrm{mtpd})$ for biomass. The gasifier is an air blown U-gas system, which Enviropower has developed further. The pilot plant includes a complete hot gas cleanup train which operates at up to $30 \mathrm{bar}(435 \mathrm{psia})$ and temperatures at up to $650^{\circ} \mathrm{C}\left(1200^{\circ} \mathrm{F}\right)$. The components of the pilot-process are presented in Figure 1.

Enviropower's IGCC hot gas cleanup concept is based on sulfur removal using different methods and particle filtration using ceramic candle filters. The bulk of fuel bound sulfur can be removed in the gasifier by means of a calcium based sorbent such as limestone or dolomite and the rest is removed externally in a fluidized bed system using a regenerable metal oxide sorbent such as zinc titanate. The sulfur removal options in Enviropower's IGCC process can be seen in Figure 2. Novel zinc titanate sorbents suitable for fluidized bed application have been tested and the plan is to use the regenerable sulfur removal system as the sole method of sulfur removal in the future. This will reduce the bulk of solid waste from the gasifier and improve the system performance and economy.

Cyclic sulfidation and regeneration tests with zinc titanate have been carried out in a 3-inch I.D. batch fluidized bed reactor which is located at the Institute of Gas Technology in Chicago. The reactor is capable of operating at temperatures up to $1000^{\circ} \mathrm{C}\left(1830^{\circ} \mathrm{F}\right)$ and pressures up to 30 bar ( 435 psia) with synthetic gas mixtures containing all the gaseous components for sulfidation and regeneration reactions. The 3 -inch pressurized fluidized bed reactor assembly has been described in detail elsewhere $/ 3 /$. The laboratory- and bench-scale test results have been reported earlier $/ 3,4,5 /$.

\section{PROJECT DESCRIPTION}

The CRADA-project consists of the following subtasks:

- Pilot-plant testing of the metal oxide sorbents is carried out in Envirpower's pilot plant, using a pressurized fluidized-bed absorber and regenerator. The sulfur removal efficiency and long term durability of the sorbent are evaluated in these tests. Sorbent samples from the pilot-plant tests are analyzed by Enviropower, 
IGT and METC.

- Laboratory-scale tests are conducted on the sorbents used at the pilot-plant for removal of hydrogen sulfide. These tests are performed in a 3 inch pressurized fluidized bed under conditions simulating the real situation with respect to temperature, pressure and gas composition. Sorbents are evaluated for their physical, chemical and mechanical durability.

- The tail gas from the regeneration contains sulfur dioxide which can be converted to usable elemental sulfur. A technology called the Direct Sulfur Recovery Process (DSRP) has been developed at Research Triangle Institute (RTI) /6/ to achieve this objective. A skidmounted DSRP unit is under construction by METC. This unit will be shipped to the pilot plant in Finland for installation and testing with a slipstream of the U-gas process coal gas. Suitability of the DSRP process and sulfur conversion efficiency will be examined during testing. Design data will also be obtained for scale-up for commercial-sized systems.

- The collection efficiency and operability of ceramic candle filters for removing particles from the hot gas have been examined in full scale pilot plant tests.

\section{RESULTS AND FUTURE WORK}

\section{Pilot-scale sulfur removal tests}

The sulfur removal pilot consists of high temperature and pressure (HTHP) fluidized-bed type sulfider and regenerator reactors and systems for fresh sorbent feeding, sorbent circulation between reactors and gas preheating/cooling for regenerator.

In 1994 two types of zinc titanate sorbents, designated as ZT-4-L and UCI-5, were tested at high pressure and temperature. ZT-4-L was manufactured by Contract Materials Processing, Inc. as a subcontractor to Research Triangle Institute (RTI) and UCI-5 was manufactured by United Catalysts Inc. The physical properties of the two sorbents, fresh and after reaction, are shown in Table 1.

UCI- 5 was tested in two coal gasification test runs with 5-6 days of continuous operation in each test. The sulfur removal efficiency after reaching steady operation can be seen in Figure 3. Typical performance of sulfider and regenerator reactors in combined operation can be seen in Figures 4 and 5. Both reactors were operating at the same pressure level as the gasifier. As can be seen from Figure 4, satisfactorily high sulfur removal efficiency in the sulfider was achieved in combined operation.

ZT-4-L was used in a test run in November 1994. The sulfur removal efficiency in the beginning of the test (coke gasification startup) can be seen in Figure 6. In comparison with Figure 3, the sulfur capture efficiency is higher than with UCI-5. This is most propably due to higher surface area, as shown in Table 1 . The regenerator performance with ZT-4-L sorbent can be seen in Figure 7 with continuous production of $\mathrm{SO}_{2}$-containing off-gas. The start-up of regeneration with ZT-4-L was more difficult than with UCI-5, as can be seen from the long (2-hour) period of increasing the bed temperature from about $520^{\circ} \mathrm{C}$ to $700^{\circ} \mathrm{C}(970$ $1300^{\circ} \mathrm{F}$ ) (Figure 7). This may be partly due to a higher dependence of reaction rate on temperature.

Nitrogen or steam was used to dilute the air in the regenerator inlet gas. UCI-5 was tested with both diluents and ZT-4-L with $\mathrm{N}_{2}$. According to the test data, steam was as effective as nitrogen, and did not show any detrimental effect on sorbent performance. 
In the beginning of the test runs a smail fraction of fines $(5-10 \mu \mathrm{m})$ was created with both sorbents, which was then elutriated from the beds. This is partly due to the attritive effect of fluidization on fresh sorbent particles as already observed in bench-scale tests. The other reason might be a slight grinding effect of the screw feeder used in sorbent injection. This can be eliminated by using some other type of sorbent feeding. The tests also showed that the amount of fine dust at the sulfider exit increases during start-up after off-balance operation periods with used sorbent. However, during steady-state combined sulfider and regenerator operation periods, bed material attrition or elutriation was satisfactory.

In order to fully determine the long-term durability of the process and sorbents tested with real coal gas, test runs of longer duration than a week are needed, which tests have not been executed so far.

\section{Pilot Tests with Ceramic Filter}

During coal gasification test runs in 1994 the major emphasis in the development of hot gas cleanup was directed towards testing of the sulfur removal system. The ceramic filter testing was already in the category of routine operation. A schematic diagram of the filter unit is shown in Figure 8. The filter unit is completely intergrated with the control system of the pilot plant. The filter cleaning strategy was mainly based on a constant cycle time using on-line pulsing with pressurized nitrogen.

The test runs were carried out with twolayered, SiC-based, round shaped ceramic candle elements. The filter unit was operated at the temperature range of $450-600^{\circ} \mathrm{C}(840$ $1110^{\circ} \mathrm{F}$ ), which will be used in the simplified IGCC applications. Figures 9, 10 and 11 show the typical filter operation and performance values. An example of the effect of the cycle time can be seen in Figure 9. The cycle time was decreased $25 \%$ due to a slight increase in $\Delta \mathrm{p}$-baseline at the beginning of the test period. After the change of the cycle time $\Delta \mathrm{p}$-baseline decreased to about $9 \mathrm{kPa}(0.13 \mathrm{psi})$ value and after that remained constant.

Dust loadings below 5 ppmw in product gas and vapour-phase alkali ( $\mathrm{Na}+\mathrm{K})$ concentrations below 0.05 ppmw were measured after filtration. These values are below the levels generally required by gas turbine manufacturers and well below the environmental standards. During operation the filter pressure drop has generally stayed low and the filter permeance constant. It should be noted, however, that long gasification periods are needed to completely verify the long term development of the filter permeability and filtration reliability.

More information on the ceramic filter behavior during biomass gasification is presented in $/ 2 /$.

\section{Laboratory-scale work}

The physical properties of the used ZT-4-L and UCI-5 sulfider and regenerator bed material samples (taken during pilot-tests) are shown in Table 1. It can be seen that for the used sorbents the particle density increases and porosity decreases. For ZT-4-L the surface area surprisingly increases, which was also observed in the laboratory tests. Figure 12 shows the sulfidation breakthrough curves for fresh and used UCI-5 samples obtained from the 3 " batch fluidized bed. The most important observation is that the physical properties of the pilotsamples change the same way as in the benchscale tests. The same goes for sulfidation and regeneration reactivity. This indicates that the conctact with real coal gas for 5-6 days has no detrimental effect on sorbent physical or chemical properties. 
Table 1 also shows the sulfate sulfur analysis for the sorbents taken from the regenerator. These analyses as well as the pilot-test results indicate that undesirable zinc sulfate is not accumulated into the sorbent (if formed at all), when operating the fluidized-bed regenerator at temperatures of $600-750^{\circ} \mathrm{C}\left(1110-1380^{\circ} \mathrm{F}\right), 2-4$ vol- $\%$ of $\mathrm{O}_{2}$ and steam or nitrogen as diluent.

\section{Modelling efforts}

A steady-state kinetic model for hot gas desulfurization system has been developed based on laboratory- and bench-scale tests with zinc titanate sorbents. The model was used in the dimensioning of the pilot and commercialscale sulfur removal systems. The results from the test runs in 1994 show that the model predictions are in good agreement with the test results. The pseudo first-order sulfidation reaction rate constants determined from pilot results indicate that the reactivity, as well as sulfur capacity of ZT-4-L is 1.5-2 times higher than of UCI-5. However, the sulfidation and regeneration performance of UCI-5 at the operating conditions tested was satisfactory for a real-scale unit.

By assuming that the regeneration reaction rate is first-order with respect to reactants (oxygen and zinc sulfide), it was possible to determine the activation energy of the reaction rate constant from the pilot-test data. The value of activation energy obtained for ZT-4-L was higher than for UCI-5, which means higher sensitivity of the rate of regeneration towards regenerator temperature.

A dynamic model for the pilot and commercial-scale post-bed sulfur removal system is under development. The objective is to use it for predicting the effects of the changes in regenerator inlet gases, sorbent transport velocity, fluidization velocities, etc., on the overall performance. This information can be used to adjust the control system of the process. The response of the regenerator dynamic model is shown in Figure 13, which should be compared with Figure 5. In the future the dynamic model will be added as a module into Enviropower's existing IGCC-plant dynamic simulator for design and training purposes.

\section{DSRP pilot design}

The DSRP skid-mounted pilot-unit is under construction by METC. The skid will be shipped to Finland by the end of September. The commissioning of the unit in connection with pilot-gasifier and sulfur removal unit will be performed towards the end of 1995.

\section{CONCLUSIONS}

During coal gasification test runs in 1994 the major emphasis in development of hot gas cleanup was focused on testing of the sulfur removal system. The ceramic filter unit testing was already in the category of routine operation. The operating temperature was 450 $600^{\circ} \mathrm{C}\left(840-1110^{\circ} \mathrm{F}\right)$ at gasifier pressures. These conditions will be used in commercialscale simplified IGCC applications.

Three test runs with two types of zinc titanate sorbent was accomplished with the sulfur removal pilot; each of them with 5-6 days of continuous operaration. The results showed that high sulfidation efficiency as well as continuous production of $\mathrm{SO}_{2}$-containing regenerator off-gas at design temperatures and pressures could be achieved. The observed difference in sulfidation reactivity between the two sorbents was related to the sorbent physical properties, like surface area. Regeneration reactivity was about the same for both sorbents and the formation of undesirable sulfate sulfur in regenerator could be avoided with steam or nitrogen as inlet diluent gases. 
The change of sorbent properties when in contact with real coal gas was the same as observed in laboratory- and bench-scale tests with simulated gases after continuous sulfidation-regeneration cycling.

In the test with ceramic filter, the dust loadings below 5 ppmw solids in the product gas and vapour-phase alkali (Na+K) concentrations below $0.05 \mathrm{ppmw}$ after the filter unit have been measured. These values are below the levels generally required by gas turbine manufacturers and well below the environmental standards. During operation the filter pressure drop has generally stayed low and the filter permeance constant.

Steady-state and dynamic models to predict and simulate the operation of sulfider and regenerator reactors have been developed. The results of pilot-scale tests are in good agreement with modelling results.

A pilot-scale process for the recovery of elemental sulfur, called DSRP, is under construction. It will be tested in combined operation with the sulfur removal pilot under the present CRADA project.

\section{REFERENCES}

1. PATEL J.G.; The simplified IGCC Process Clean Coal Technology for Power Generation. Paper presented at Comparative Economics of Emerging Clean Coal Technologies III: Advanced Power \& Environmental Control. Washington, DC, USA, February $28 \&$ March $1,1994$.

2. LIINANKI, L., HORVATH, A., LEHTOVAARA, A. AND LINDGREN, G.; The Development of a Biomass Based Simplified IGCC Process. In: Thirteenth EPRI
Conference on Gasification Power Plants, San Francisco, USA, October 19-21, 1994.

3. ABBASIAN J., BACHTA R.P., WANGEROW J. R., MOJTAHEDI W., SALO K.; Advanced High-Pressure Bench-Scale Reactor for Testing with Hot Corrosive Gases. Ind. Eng. Chem. Res. 33(1994)1.

4. MOJTAHEDI W., SALO K., ABBASIAN J.; Desulfurization of hot coal gas in fluidized bed with regenerable zinc titanate sorbents. Fuel Processing Technology 37(1994) 53-65.

5. KONTTINEN J., MOJTAHEDI W.; Gasifier gas desulfurization at high temperature and pressure. Kemia-Kemi (Finnish Chemistry) (1993)11-12. (In English)

6. GANGWAL S.K., PORTZER, J.W., HOWE G.B., CHEN D.H., MCMILLIAN M.H.; Slipstream Testing of the Direct Sulfur Recovery Process. In: Proceedings of the CoalFired Power Systems 94 -- Advances in IGCC and PFBC Review Meeting, Volume 1. Morgantown, WV, USA, June 21-23, 1994. 
Table 1. The Physical Properties of the Fresh and Used Zine Titanate Sorbents.

\begin{tabular}{|c|c|c|c|c|c|c|}
\hline Property & $\begin{array}{l}\text { Fresh } \\
\text { UCI-5 }\end{array}$ & $\begin{array}{l}\text { UCI-5, } \\
\text { Sulfider } \\
\text { sample } \\
\text { *) }\end{array}$ & $\begin{array}{l}\text { UCI-5, Re- } \\
\text { generator } \\
\text { sample } \\
\text { *) }\end{array}$ & $\begin{array}{l}\text { Fresh } \\
\text { ZT-4-L }\end{array}$ & $\begin{array}{l}\text { ZT-4-L } \\
\text { Sulfider } \\
\text { sample } \\
\text { *) }\end{array}$ & $\begin{array}{l}\text { ZT-4-L } \\
\text { Regenera- } \\
\text { tor } \\
\text { sample *) }\end{array}$ \\
\hline $\begin{array}{l}\text { Particle } \\
\text { Density } \\
{\left[\mathrm{g} / \mathrm{cm}^{3}\right]}\end{array}$ & 2.26 & 2.51 & 2.44 & 2.14 & 2.46 & 2.38 \\
\hline $\begin{array}{l}\text { Pore } \\
\text { volume } \\
{\left[\mathrm{cm}^{3} / \mathrm{g}\right]}\end{array}$ & 0.26 & 0.128 & 0.172 & 0.22 & 0.12 & 0.17 \\
\hline $\begin{array}{l}\text { Surface } \\
\text { Area } \\
{\left[\mathrm{m}^{2} / \mathrm{g}\right]}\end{array}$ & 1.4 & 4.3 & 1.2 & 3.5 & 11.1 & 5.5 \\
\hline $\begin{array}{l}\text { Median } \\
\text { pore } \\
\text { diam. } \\
[\AA]] \\
\end{array}$ & - & 5000 & - & 2700 & 1600 & 2200 \\
\hline $\begin{array}{l}\text { S-sulfide } \\
\text { [w-\%] }\end{array}$ & 0.019 & 9.31 & 0.29 & 0.01 & 10.3 & 3.86 \\
\hline $\begin{array}{l}\text { S-sulfate } \\
\text { [w-\%] }\end{array}$ & 0.057 & 0.11 & 0.14 & 0.03 & 0.11 & 0.038 \\
\hline $\begin{array}{l}\text { Dp, Avg } \\
{[\mu \mathrm{m}]}\end{array}$ & 287 & 267 & 285 & 239 & 223 & 237 \\
\hline
\end{tabular}

*) Samples were taken in the end of each test run. 


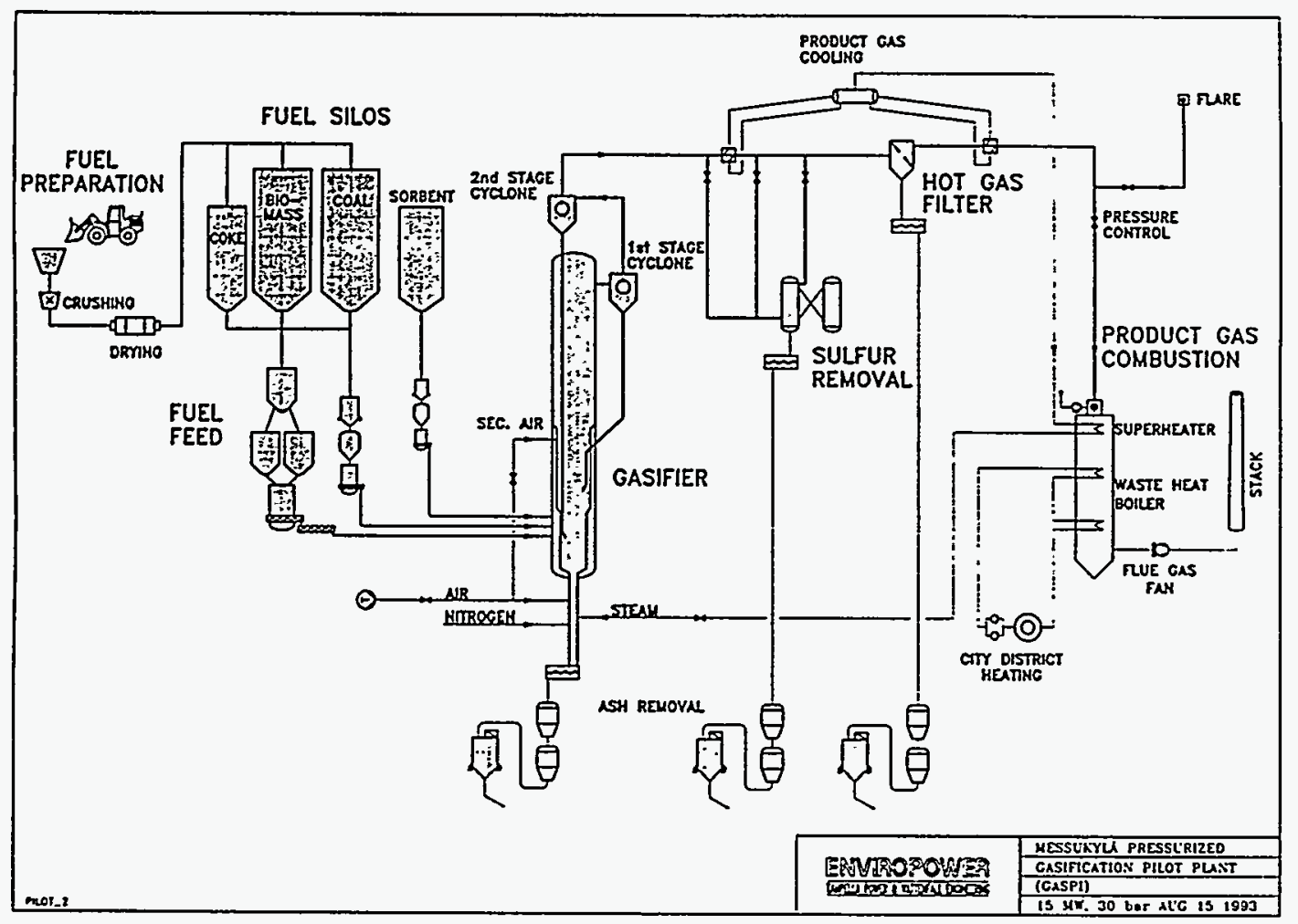

Figure 1. Enviropower's Pressurized Gasification Pilot Plant.

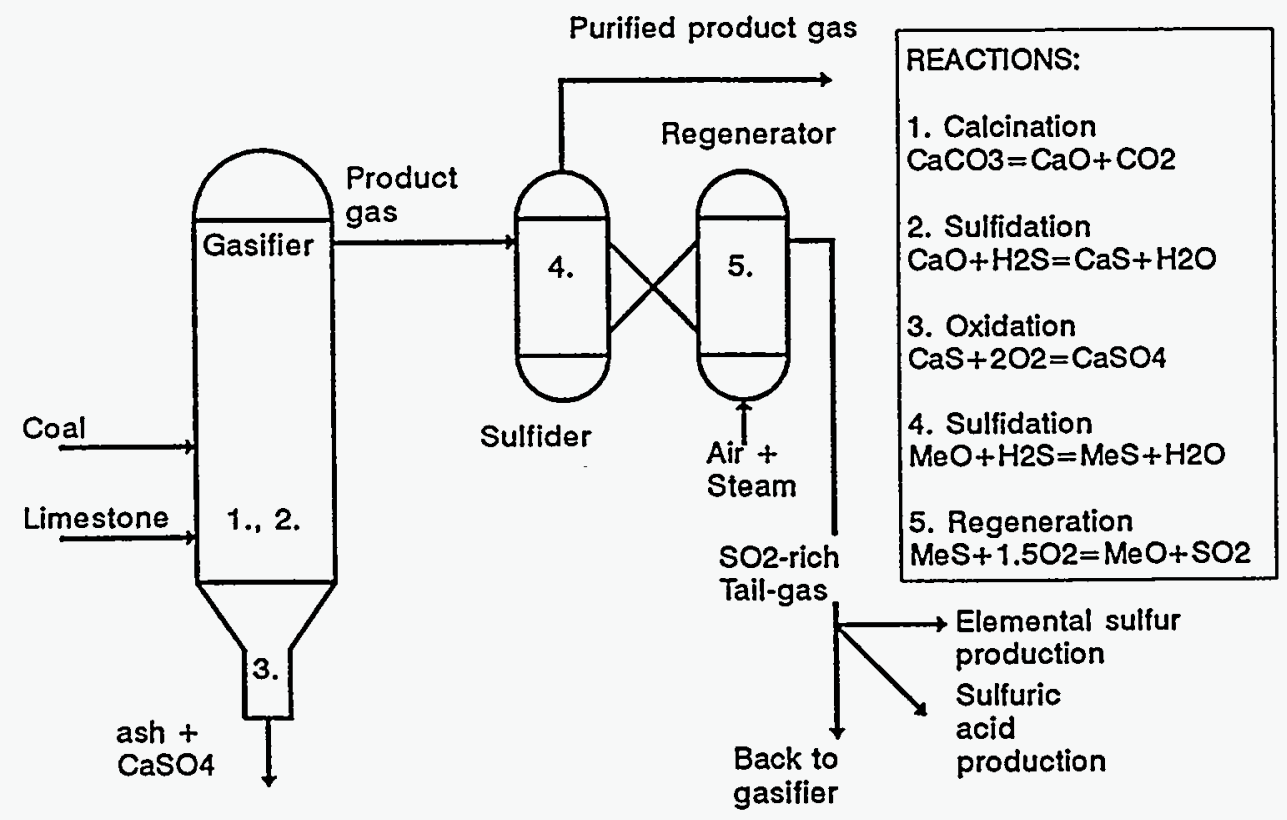

ENVIROPOWER

Figure 2. Tampella's Initial Concept for Sulfur Removal. 


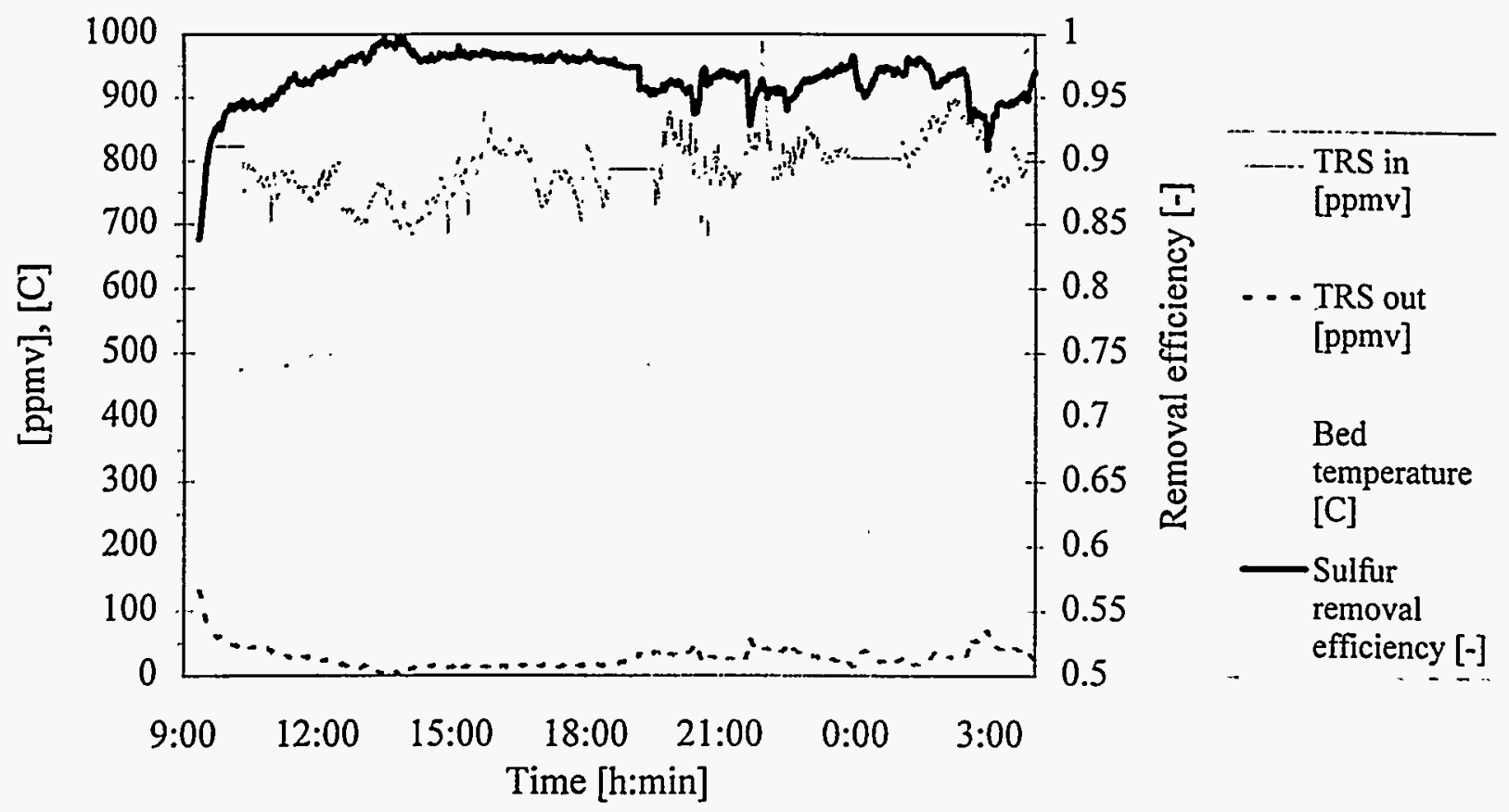

Figure 3. Sulfur Removal Efficiency with UCI-5-sorbent in the Beginning of Test Run. (TRS = Total Reduced Sulfur)

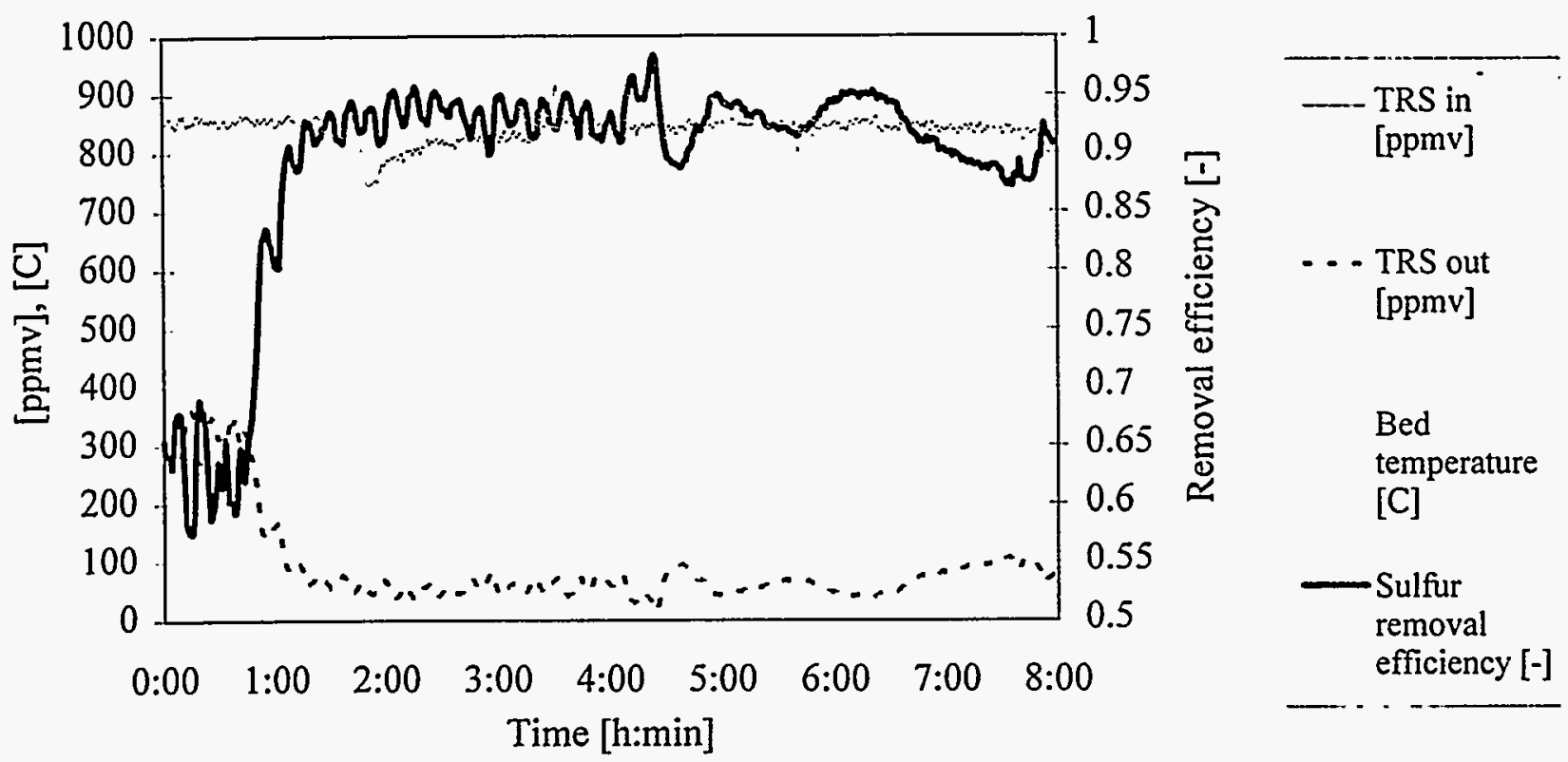

Figure 4. UCI-5 Sulfur Removal Efficiency when Both Sulfider and Regenerator On-Line. 


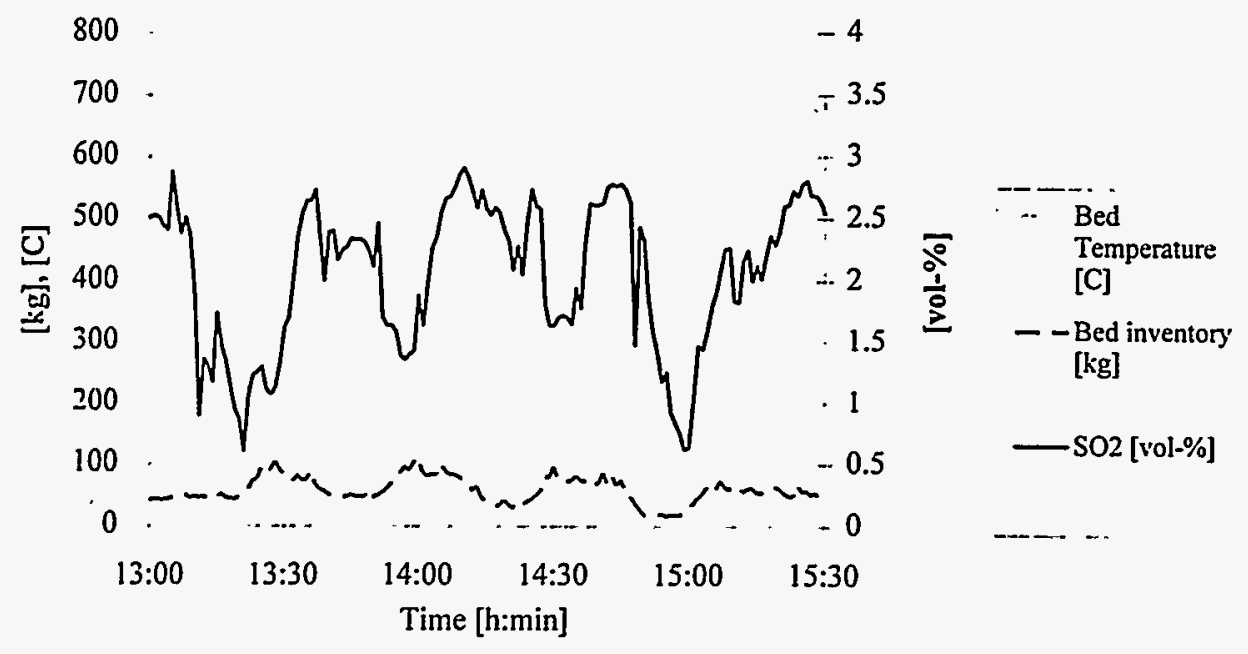

Figure 5. Regenerator Performance with UCI-5- Sorbent.

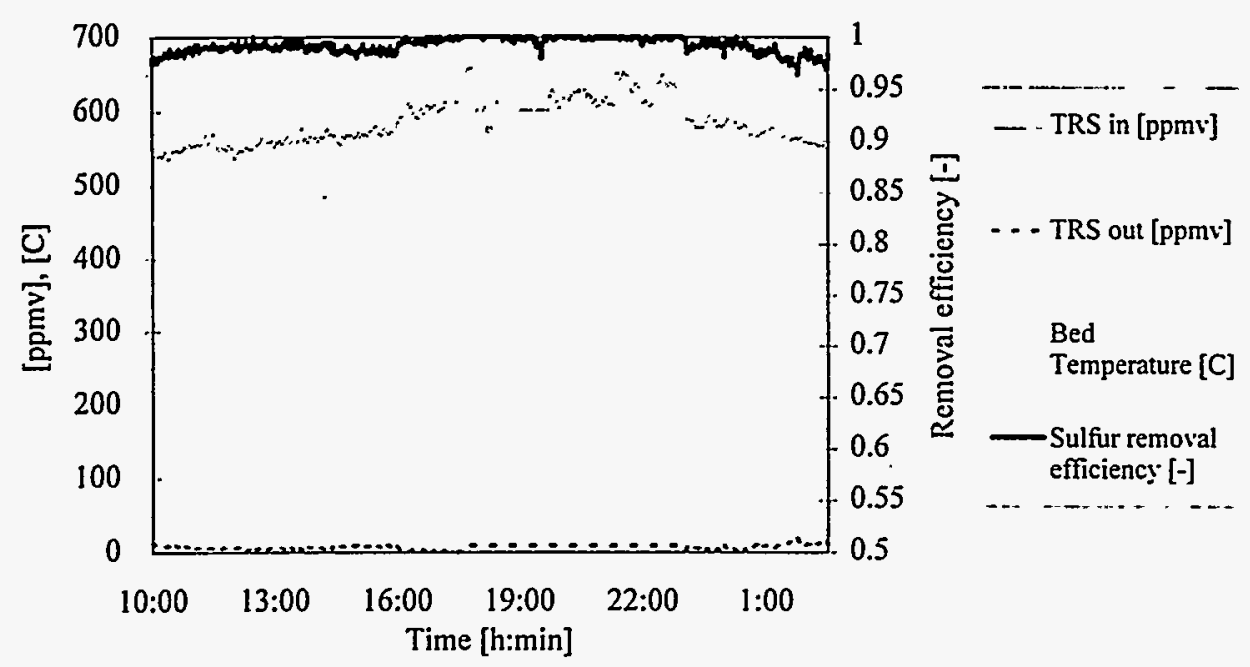

Figure 6. Sulfur Removal Efficiency with ZT-4-L-Sorbent.

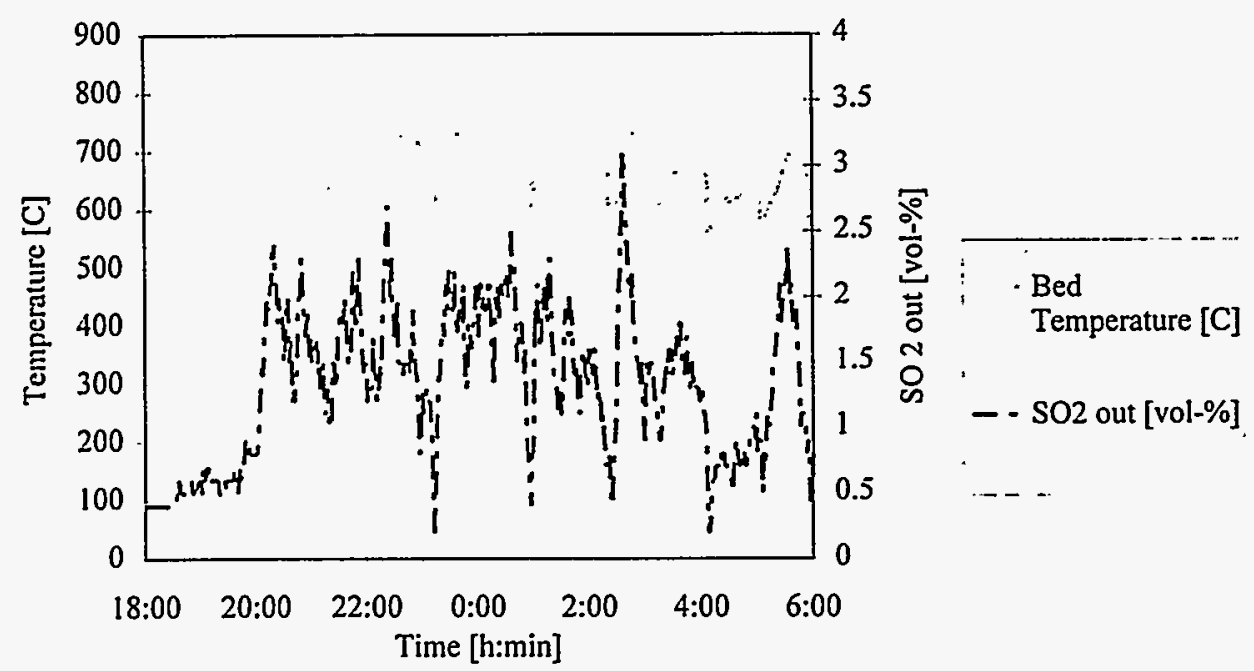

Figure 7. Regenerator Performance with ZT-4-L- Sorbent. 


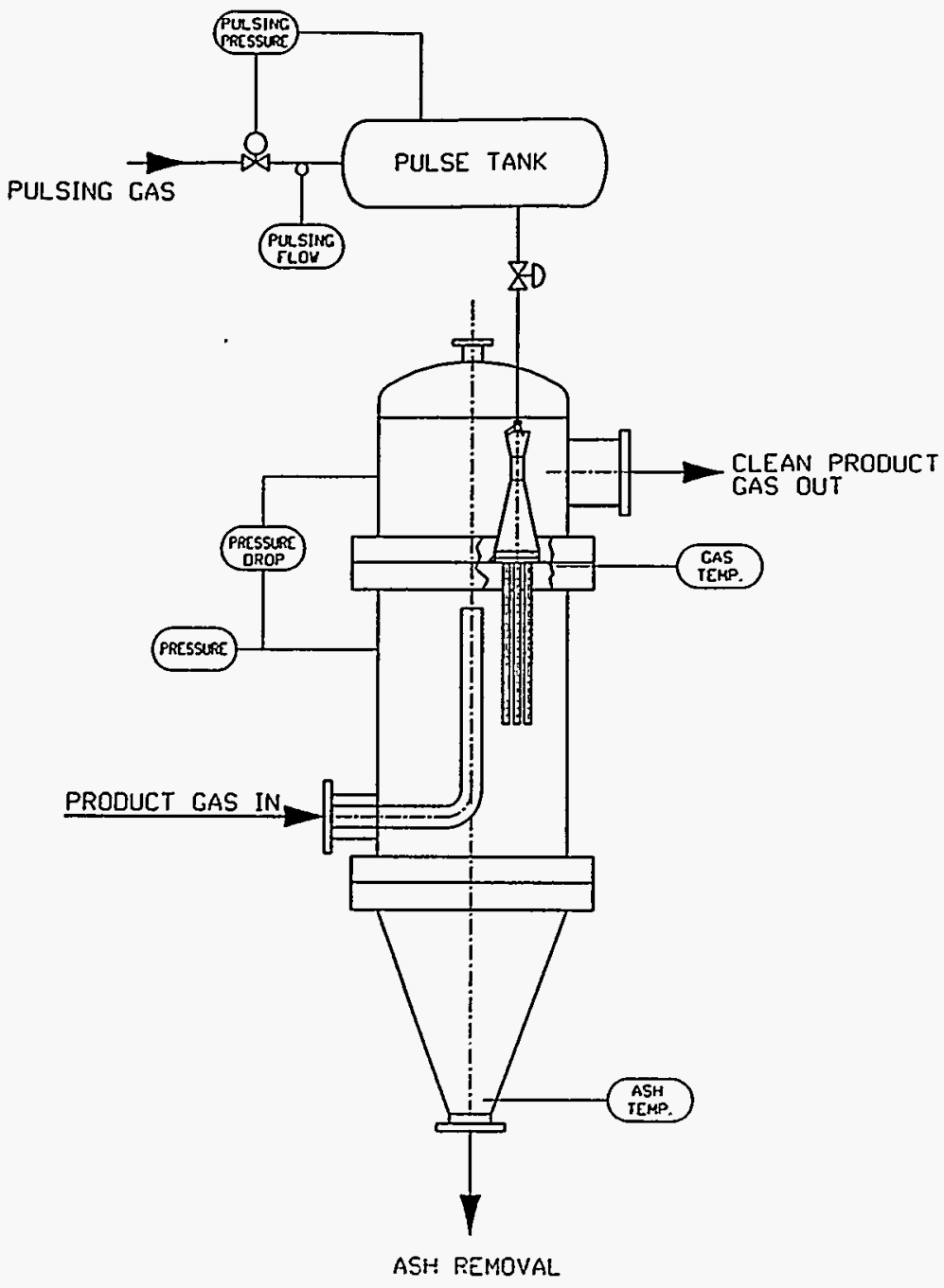

Figure 8. Pilot Filtration Unit.

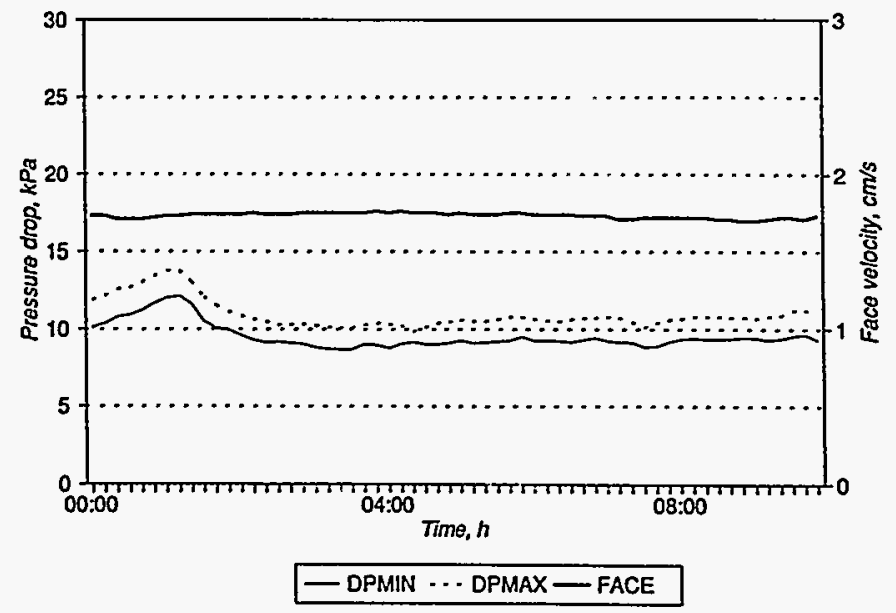

Figure 9. Filter Pressure Drop Across the Filter Elements and Face Velocity (dpmin and dpmax are minimum and maximum pressure drops, respectively). 


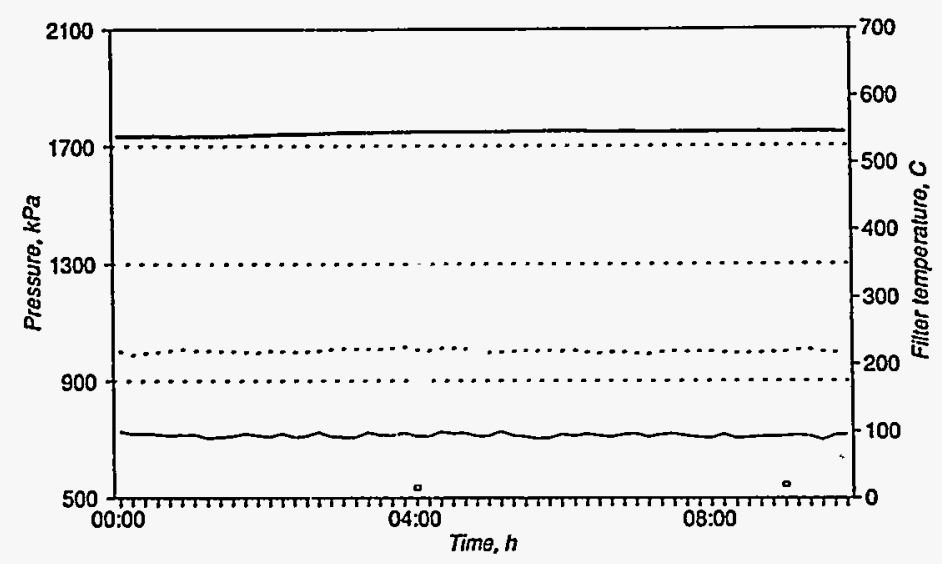

PULSING PRESSURE $\cdots$ - . GASIFIER PRESSURE — FILTER TEMP.

Figure 10. Filter Pulsing Pressure, Product Gas Pressure and Temperature.

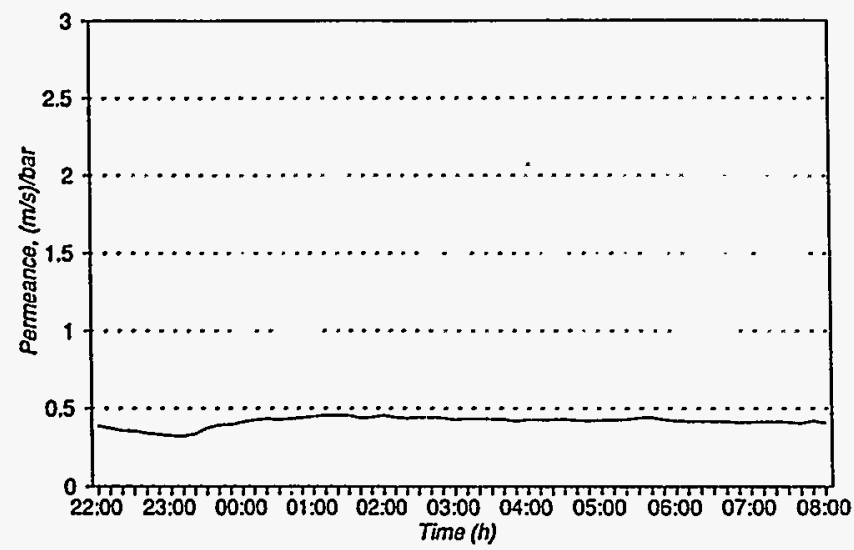

Permeance

Figure 11. Filter Permeance. 


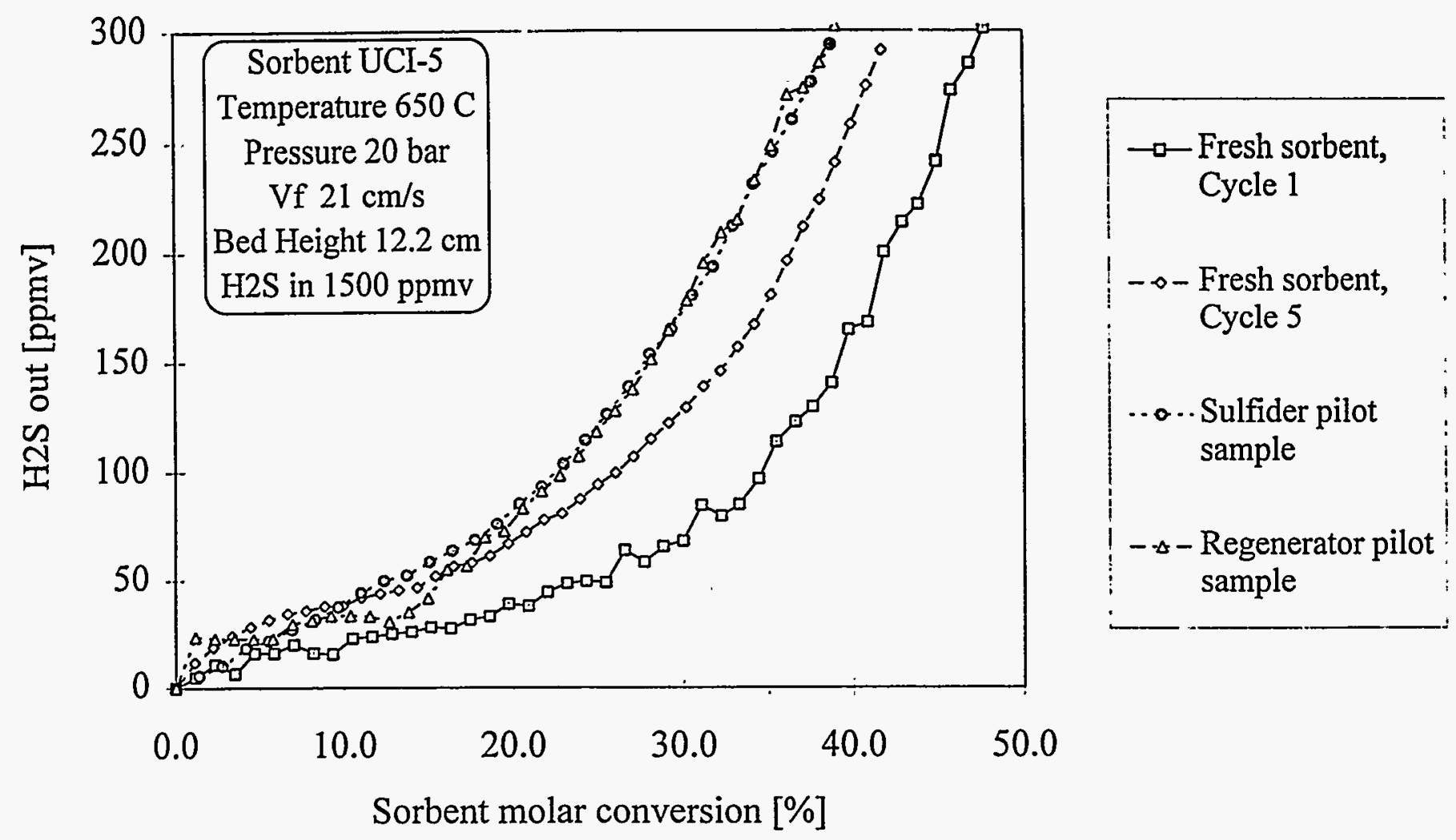

Figure 12. Comparison of Sulfidation Breakthrough Curves in 3" Batch BFB Reactor with UCI-5Sorbent

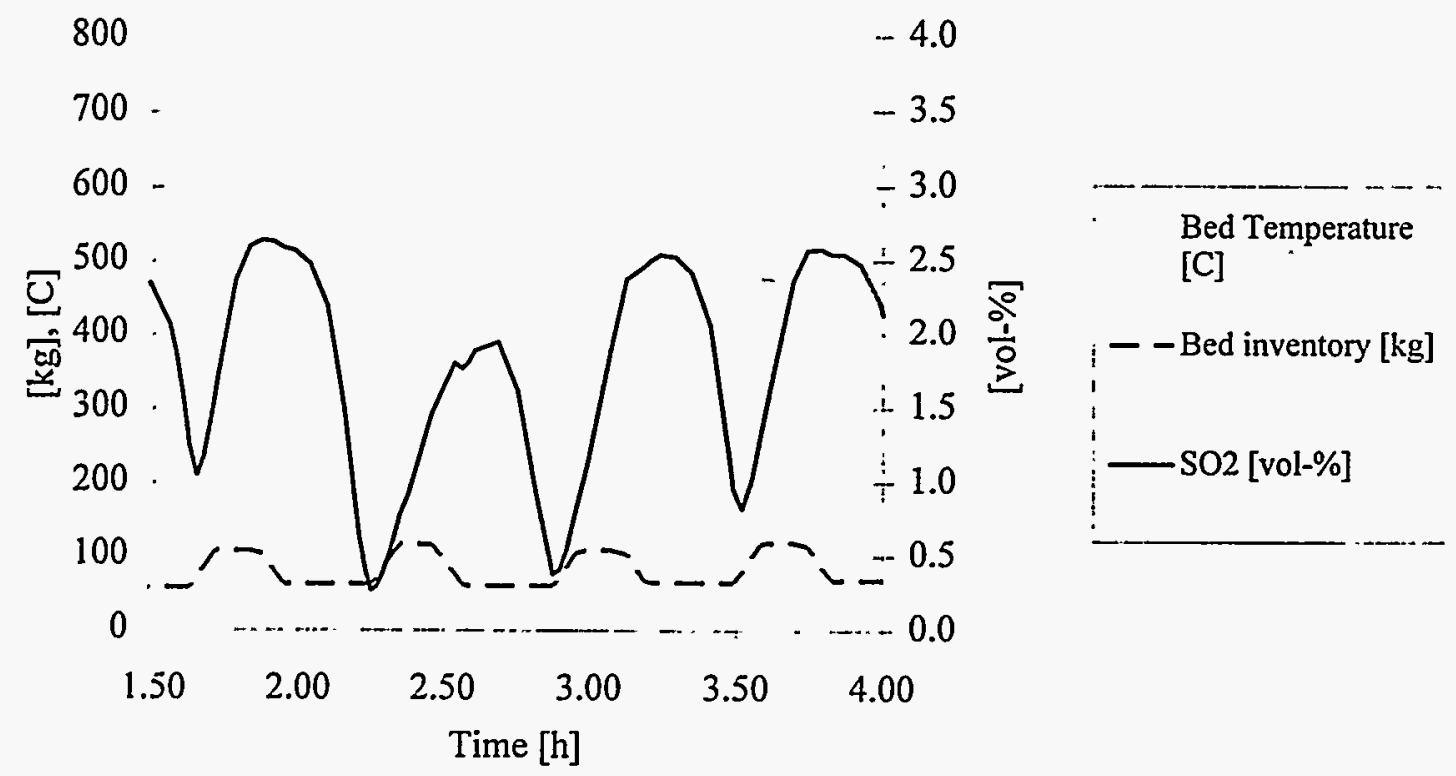

Figure 13. Regenerator Dynamic Model Response (in comparison with real situation in Figure 5). -214 - 